\title{
Preparation of $\mathrm{IrO}_{2}-\mathrm{Ta}_{2} \mathrm{O}_{5} \mid \mathrm{Ti}$ electrodes by immersion, painting and electrophoretic deposition for the electrochemical removal of hydrocarbons from water
}

Rosa Alhelí Herrada ${ }^{\mathrm{a}, \mathrm{b}}$, Alejandro Medel ${ }^{\mathrm{a}, \mathrm{b}}$, Federico Manríquez ${ }^{\mathrm{a}}$, Ignasi Sirés ${ }^{\mathrm{b}, *}$, Erika Bustos ${ }^{\mathrm{a}, * *}$

a Centro de Investigación y Desarrollo Tecnológico en Electroquímica, S.C. Parque Tecnológico Querétaro, Sanfandila, Pedro Escobedo, 76703 Querétaro, Mexico

${ }^{b}$ Laboratori d'Electroquímica dels Materials i del Medi Ambient, Departament de Química Física, Facultat de Química, Universitat de Barcelona, Martí i Franquès 1-11, 08028 Barcelona, Spain

Article submitted for publication in the Journal of Hazardous Materials

*Corresponding author: $\quad$ Tel.: +34 934039240; fax: +34 934021231.

E-mail address: i.sires@ub.edu (Ignasi Sirés)

**Corresponding author: Tel.: +52 44221160 59; fax: +52 4422116001 .

E-mail address: ebustos@cideteq.mx (Erika Bustos) 


\begin{abstract}
After intense years of great development, the electrochemical technologies have become very suitable alternatives in niche markets like industrial wastewater reclamation and soil remediation. A key role to achieve a high efficiency in such treatments is played by the characteristics of the coating of the electrodes employed. This paper compares three techniques, namely immersion, painting and electrophoresis, for the preparation of $\mathrm{IrO}_{2}$ $\mathrm{Ta}_{2} \mathrm{O}_{5} \mid \mathrm{Ti}$, so-called dimensionally stable anodes $\left(\mathrm{DSA}^{\circledR}\right)$. The quality of the coatings has been investigated by means of surface and electrochemical analysis. Their ability to generate hydroxyl radicals and degrade aqueous solutions of hydrocarbons like phenanthrene, naphthalene and fluoranthene has been thoroughly assessed. Among the synthesis techniques, electrophoretic deposition yielded the best results, with DSA $^{\circledR}$ electrodes exhibiting a homogeneous surface coverage that led to a good distribution of active sites, thus producing hydroxyl radicals that were able to accelerate the degradation of hydrocarbons.
\end{abstract}

Keywords: Dimensionally Stable Anode; Electro-oxidation; Hydrocarbon; Hydroxyl radical; Water treatment. 


\section{Introduction}

The increase in generation, improper disposal and accidents such as leaks, spills and fires of hazardous waste causes a severe pollution problem worldwide, which results in the deterioration of water bodies, air and soil. These situations represent a potential risk to both, public health and the environment [1-5]. Contamination should be rather prevented but, even after its occurrence, there are several methods for counteracting it. According to the Environmental Protection Agency, the term "remediation technologies" refers to any technique or operation that alters the composition of one or more hazardous and polluting substances, mainly through chemical, physical or biological actions in order to reduce toxicity and pollution of the site. Among them, the electrochemical methods have received great attention in recent years [2].

The efficacy of the electrochemical technologies depends on the physical and chemical properties of contaminants and those of the polluted compartment. These processes are most usually performed by applying a direct current between the anode and cathode, thus creating a small potential difference or electric field that promotes the transport of ions and positively charged compounds, as well as the generation of highly oxidizing species. As a result, in some electrochemical reactors, contaminants may be degraded by physisorbed hydroxyl radical $\mathrm{M}\left({ }^{\bullet} \mathrm{OH}\right)$ produced as intermediate of water discharge to $\mathrm{O}_{2}$ at the anode surface $\mathrm{M}$, as follows [6,7]:

$$
\mathrm{M}+\mathrm{H}_{2} \mathrm{O} \rightarrow \mathrm{M}\left({ }^{\bullet} \mathrm{OH}\right)+\mathrm{H}^{+}+\mathrm{e}^{-}
$$

Nowadays, electrochemical remediation is considered a reality rather than a promise for solving environmental problems, especially for water reclamation. In particular, several articles and patents have been published regarding the degradation of hydrocarbons [8-14]. 
Although the electrochemical treatments may offer excellent efficiencies for the removal of pollutants such as hydrocarbons (for some arrangements, removal efficiencies are higher than $80 \%$ ), they also entail a high investment costs due to the type of electrodes required as anodes, which typically are boron-doped diamond (BDD) thin films or coatings made of oxides of transition metals such as $\mathrm{IrO}_{2}, \mathrm{RuO}_{2}, \mathrm{SnO}_{2}$ and $\mathrm{Ta}_{2} \mathrm{O}_{5}$ [15]. The latter ones are known as dimensionally stable anodes $\left(\mathrm{DSA}^{\circledR}\right)$, and are routinely used for the electro-oxidation of organic pollutants contained in water, being the degradation processes rather slow because it is confined to the electrocatalytic surface layer where oxidants species are generated $[19,20]$. DSA ${ }^{\circledR}$ electrodes allow the transport of electric charge between the metal substrate, which is usually made of $\mathrm{Ti}$, and the coating-electrolyte interface. These materials are very appealing for scale-up of electrochemical water treatment because of their high chemical and electrochemical stability, low cost and great ability to catalyze electrochemical reactions [21]. Some DSA ${ }^{\circledR}$ electrodes are particularly suitable for producing hydroxyl radicals at the interface level, which promotes the transformation of pollutants into less toxic compounds [22,23]. $\operatorname{IrO}_{2}$-based $\mathrm{DSA}^{\circledR}$ is especially interesting because of its high corrosion resistance, being quite similar to $\mathrm{RuO}_{2}$ based $\mathrm{DSA}^{\circledR}$ in terms of electrocatalysis [22,23]. The most common $\mathrm{IrO}_{2}$ coatings incorporate $\mathrm{Ta}_{2} \mathrm{O}_{5}$ as stabilizing agent, since it is chemically and electrochemically stable, also preventing isolation between the substrate and the upper catalyst layer because of its ability to hinder the passivation of the former one [22].

On the basis of the above considerations, studies on coating quality enhancement are mandatory in order to increase the performance of electrochemical remediation, having a major impact on catalytic properties and stability against corrosion [24]. 
This paper compares the preparation of titanium electrodes coated with $\mathrm{IrO}_{2}$ and $\mathrm{Ta}_{2} \mathrm{O}_{5}$ by three different techniques, namely immersion (I), painting (P) and electrophoretic deposition (EP). Morphological and electrochemical analyses were then performed by scanning electron microscopy (SEM) coupled with energy dispersive X-ray spectroscopy (EDX) and cyclic voltammetry (CV), respectively, whereas the generation of hydroxyl radicals was monitored by UV/vis spectroscopy, high performance liquid chromatography (HPLC) with fluorescence detection and electron paramagnetic resonance (EPR). In addition, the performance of the DSA ${ }^{\circledR}$ electrodes regarding the destruction of polycyclic aromatic hydrocarbons (PAHs) like phenanthrene, naphthalene and fluoranthene in aqueous solution was assessed by means of HPLC and total organic carbon (TOC) analyses.

\section{Experimental}

\subsection{Electrode preparation}

The precursor solution contained $\mathrm{H}_{2} \mathrm{IrCl}_{6}$ (Strem Chemicals, 99.9\%) [22,23,25-28], dissolved in hydrochloric acid [20,21], and $\mathrm{TaCl}_{5}$ (Strem Chemicals, 99.9\%) [20-23], dissolved in isopropanol [22]. After vigorous stirring, both solutions were mixed and the metal (Ir:Ta) weight ratio in the precursor solution was 20:80. Titanium plates employed as substrate $(5 \mathrm{~mm} \times 15 \mathrm{~mm})$, were first sandblasted [20,22,23,25] and then etched with a $40 \%$ oxalic acid solution [20,25,26,28] for 20 min, thereby being rinsed with deionized water and finally dried. The application of the precursor solution on the substrate was comparatively carried out by three techniques (I, P and EP). The immersion procedure required introducing the titanium plate into the precursor solution for 20 min under constant stirring [27]. For painting, the modifier solution was applied onto the Ti plate by using a 
brush [20,25]. The electrophoretic deposit was obtained at a constant current density of 14 $\mathrm{mA} \mathrm{cm}{ }^{-2}$ for 20 min under constant stirring of $250 \mathrm{rpm}$ [29]. For I and P procedures, the experimental conditions were taken from literature [20,25,27], whereas for EP, the experimental parameters except the current density that was optimized in this work were taken from literature [29]. In all cases, metal oxides were obtained upon thermal decomposition in two steps, the first one at $523 \mathrm{~K}$ for $10 \mathrm{~min}$ and the second one at $723 \mathrm{~K}$ for $1 \mathrm{~h}[20,22,27,29]$. All the coatings were synthesized in triplicate.

\subsection{Microstructural analysis}

The morphological characteristics of the synthesized electrodes were evaluated by SEM, while the distribution of iridium and tantalum throughout the coating was analyzed by EDX, using a Jeol JSM6500 microscope operating at $15 \mathrm{kV}$ and equipped with an EDX Oxford Inca 300 analyzer.

\subsection{Electrochemical characterization}

Cyclic voltammograms were obtained to characterize and compare the three types of DSA $^{\circledR}$ electrodes. For each $\mathrm{IrO}_{2}-\mathrm{Ta}_{2} \mathrm{O}_{5} \mid \mathrm{Ti}$ anode as working electrode, the experiments were performed in a $10 \mathrm{~mL}$ glass cell with $0.5 \mathrm{M} \mathrm{H}_{2} \mathrm{SO}_{4}$ (J. T. Baker, 98\%) as supporting electrolyte at $298 \mathrm{~K}$, using a Pt wire (BASi) and an $\mathrm{Ag} \mid \mathrm{AgCl}(3 \mathrm{M} \mathrm{NaCl}, \mathrm{BASi})$ as counter and reference electrodes, respectively, and a BAS-Epsilon Trade Mark potentiostat from Bioanalytical Systems Inc. Prior to measurements, the solutions were deaerated by bubbling ultra-pure nitrogen (Praxair, grade 5.0) for at least $10 \mathrm{~min}$, and this gas was also gently blown over the solution during the experiments. Aiming to obtain the real area of each modified electrode, the capacitive current of the double-layer generated was calculated using the following equation [30]: 
$i=\left(\frac{d q}{d t}\right)\left(\frac{d E}{d E}\right)=\left(\frac{d q}{d E}\right)\left(\frac{d E}{d t}\right)=C_{d l}(v)$

The data were obtained from cyclic voltammograms at different scan rates $(v=0.020$ to $0.100 \mathrm{~V} \mathrm{~s}^{-1}$ ), using a potential window of $\pm 10 \mathrm{mV}$ around the equilibrium potential. Hence, the $i_{\text {cap }}$ was calculated as follows [30]:

$i_{c a p}=\left(\frac{\left|i_{c a p}^{a}\right|+\left|i_{c a p}^{c}\right|}{2}\right) v s . v$

where $i_{c a p}^{a}$ is the anodic capacitive current (in A), and $i_{c a p}^{c}$ is the cathodic capacitive current (in A). The slope of the linear relationship is the double-layer capacitance $\left(C_{d l}\right)$. The standard capacitance $\left(C_{\mathrm{st}}\right)$ used to evaluate the area was $60 \mu \mathrm{F} \mathrm{cm}^{-2}$ to roughness electrode [30]. As a result, the real area can be calculated as follows [30]:

$A_{\text {real }}=\frac{C_{d l}}{C_{s t}}$

where $C_{d l}$ is the double-layer capacitance (in F) and $A_{\text {real }}$ is the real area (in $\mathrm{cm}^{2}$ ). From the relationship of this real area and the geometric area, $A_{g e o}$, it is possible to obtain the roughness factor $(R)[30]$ :

$R=\frac{A_{\text {real }}}{A_{\text {geo }}}$

All the tests were carried out in triplicate for each electrode.

\subsection{Determination of hydroxyl radicals}

Aiming to demonstrate the generation of hydroxyl radicals, ${ }^{\circ} \mathrm{OH}$, changes in concentration of coumarin (Aldrich, 99\%) were monitored by UV/vis spectroscopy (Perkin Elmer) in the range $200-800 \mathrm{~nm}$ and, at the same time, the accumulation of 7 - 
hydroxycoumarin was revealed by HPLC using a Shimadzu LC-10ADVP chromatograph equipped with a Hypersil ODS $5 \mu \mathrm{m}, 150 \mathrm{~mm} \times 3 \mathrm{~mm}$, column from Thermo Electron, and coupled to a Shimadzu RF-10AXL fluorescence detector. The flow rate was $0.5 \mathrm{~mL} \mathrm{~min}{ }^{-1}$, with excitation and emission wavelengths of $325 \mathrm{~nm}$ and $400 \mathrm{~nm}$, respectively. The goal of these measurements was to observe changes in the solution absorbance related to the degradation of coumarin by hydroxyl radicals, as well as in the fluorescence signal upon formation of the hydroxylated by-product 7-hydroxycoumarin, according to the following reaction [31,32]:

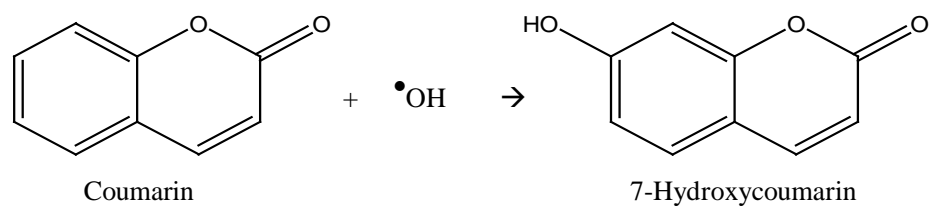

7-Hydroxycoumarin concentration was monitored at either constant current density of $30 \mathrm{~mA} \mathrm{~cm}^{-2}$ or different constant anode potentials (between 0 and $2.2 \mathrm{~V}$ vs. Ag|AgCl) using a three-electrode electrochemical glass cell with the corresponding DSA ${ }^{\circledR}$, a Pt wire and $\mathrm{Ag} \mid \mathrm{AgCl}(3 \mathrm{M} \mathrm{NaCl})$ as working, counter and reference electrodes, respectively. The electrolyses were performed with $0.3 \mathrm{mM}$ coumarin in $0.5 \mathrm{M} \mathrm{H}_{2} \mathrm{SO}_{4}$ as supporting electrolyte, at room temperature under constant stirring. Samples were withdrawn at different time periods along $180 \mathrm{~min}$. On the other hand, ${ }^{\bullet} \mathrm{OH}$ was evaluated by spin trapping, based on changes in the concentration of 5,5-dimethyl-1-pyrroline- $N$-oxide (DMPO), which forms an adduct with such radicals as reported in the literature [33]:

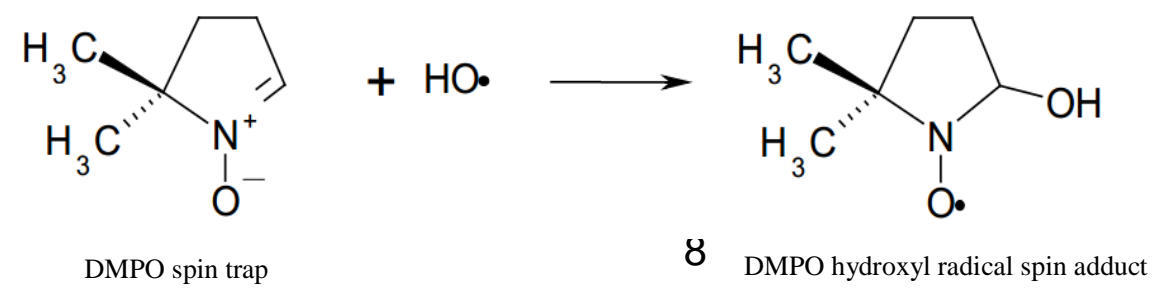


Such an adduct can be monitored by means of EPR [34,35]. For these experiments, the same three-electrode electrochemical cell described above was used to electrolyze $10 \mathrm{mM}$ DMPO in $0.5 \mathrm{M} \mathrm{H}_{2} \mathrm{SO}_{4}$ at $2.2 \mathrm{~V}$ vs. $\mathrm{Ag} \mid \mathrm{AgCl}$ and room temperature under constant stirring with a magnetic bar. Samples were withdrawn after 180 min and immediately frozen with dry ice for ensuring preservation, being finally analyzed by both, UV/vis spectrophotometry in the range 200-300 nm and EPR. For the latter analysis, samples were monitored on a Bruker ESP300E spectrometer controlled by Win-EPR SimFonia 2.3 software under the following conditions: X Band $100 \mathrm{kHz}$, modulation frequency with 1.5 G application, microwave power $10 \mathrm{~mW}$, central magnetic field 3,350 G and sweep width $100 \mathrm{G}$. Al the tests were carried out in triplicate for each DSA ${ }^{\circledR}$ type.

\subsection{Degradation of hydrocarbons in water}

The degradation of aqueous solutions of hydrocarbons such as phenanthrene, naphthalene and fluoranthene was monitored by HPLC. A two-electrode electrochemical cell with 100 -mL capacity was employed, using the DSA ${ }^{\circledR}$ synthesized by EP as the anode

and a Pt plate as the cathode. The electrolyses were performed at $30 \mathrm{~mA} \mathrm{~cm}^{-2}$ and room temperature at natural $\mathrm{pH}$ (i.e., without $\mathrm{pH}$ adjustment), using $0.5 \mu \mathrm{M}$ of phenanthrene (Acros Organics, 97\%), naphthalene (Alfa Aesar, 99\%) or fluoranthene (Sigma-Aldrich, 98\%) in $0.05 \mathrm{M} \mathrm{Na}_{2} \mathrm{SO}_{4}$ as supporting electrolyte under constant stirring with a magnetic bar. Samples were withdrawn after different time periods along the 180-min trials, and then analyzed using a Kontron HPLC model 465 quipped with a Waters Spherisorb ODS2 5 m, 
$4.6 \mathrm{~mm} \times 150 \mathrm{~mm}$, at $308 \mathrm{~K}$. All the tests were carried out in triplicate for each hydrocarbon.

Furthermore, in some case, the electrolyses were carried out for $420 \mathrm{~min}$ in order to monitor the hydrocarbon degradation by measuring the solution TOC on a Shimadzu VCSH TOC analyzer. Samples were withdrawn from treated solutions, filtered with 0.45 $\mu \mathrm{m}$ PTFE filters purchased from Whatman and directly injected into the analyzer, obtaining reproducible values with $\pm 1 \%$ accuracy. All the tests were carried out in triplicate.

\subsection{Stability of the $\mathrm{IrO}_{2}-\mathrm{Ta}_{2} \mathrm{O}_{5}$ coating}

The chemical resistance or stability of the $\mathrm{IrO}_{2}-\mathrm{Ta}_{2} \mathrm{O}_{5}$ coatings prepared by electrophoretic deposition was demonstrated from the evaluation of the Ir and Ta contents in solution after exhaustive electrolyses in $0.5 \mathrm{M} \mathrm{H}_{2} \mathrm{SO}_{4}$ at $30 \mathrm{~mA} \mathrm{~cm}^{-2}$ for $24 \mathrm{~h}$. The analysis was carried out by inductively coupled plasma optical emission spectrometry (ICPOES) using an OPTIMA 3200RL apparatus.

\section{Results and discussion}

\subsection{Microstructural analysis}

Once prepared, each type of electrode was analyzed by SEM-EDX in order to compare their morphological characteristics as well as the distribution of iridium and tantalum throughout the coating. Fig. $1 \mathrm{~A}$ and $1 \mathrm{~B}$ show the microstructure of $\mathrm{DSA}^{\circledR}$ after modification by EP, P and I electrodes, at a lower and higher magnification, respectively. The electrodes present the typical cobblestone morphology, as reported for $\mathrm{IrO}_{2}$-based coatings upon different preparation procedures [21,25,28,29]. However, it is worth noting that the surface morphologies depend to some extent on the synthesis method. For example, 
DSA $^{\circledR}$ obtained by electrophoretic deposition shows a larger number of cracks and, furthermore, they are wider and deeper (see images at 5000x) than those appearing upon immersion or painting. It is clear that immersion was the less aggressive method, leading to a smoother surface with only some small cracks.

On other hand, the relative content of Ti, Ir and Ta on the coatings can be seen in Fig. 2A-C. The DSA ${ }^{\circledR}$ electrode prepared by electrophoretic deposition exhibits the highest content of Ir and Ta, in concomitance with the lowest content of Ti (Fig. 2A). This means that the surface coverage is much more homogeneous and uniform, with a metal loading of $19.15 \mathrm{mg} \mathrm{cm}^{-2}$, than in the case of DSA ${ }^{\circledR}$ prepared by painting and immersion, which progressively exhibited lower amounts of Ir and Ta and greater signals corresponding to $\mathrm{Ti}$ (Fig. 2B and 2C, respectively), regardless of their greater metal loadings of 33.33 and 20.93 $\mathrm{mg} \mathrm{cm}^{-2}$, respectively. The poor quality of the electrode synthesized by immersion, as deduced from the large abundance of $\mathrm{Ti}$, suggests a low catalytic behavior of the coating for water decontamination and thus, this kind of electrode was discarded for subsequent tests. In contrast, the much better distribution of metals in DSA ${ }^{\circledR}$ modified by EP and P procedures is confirmed by the mapping with EDX analysis shown in Fig. 3A and B, respectively. Ir and Ta were homogeneously distributed, with the $\mathrm{IrO}_{2}-\mathrm{Ta}_{2} \mathrm{O}_{5}$ layer accounting for a surface coverage close to $250-450 \mathrm{~nm}$.

\subsection{Electrochemical characterization}

The cyclic voltammograms of three different electrodes, namely uncoated titanium substrate, DSA ${ }^{\circledR}$ prepared by electrophoretic deposition and DSA ${ }^{\circledR}$ prepared by painting, are depicted in Fig. 4. The behavior of DSA ${ }^{\circledR}$ modified by painting is quite similar to that of uncoated Ti, with current being zero until a steep increase appeared at an anode potential of 
0-0.16 V vs. Ag|AgCl due to $\mathrm{O}_{2}$ evolution from $\mathrm{H}_{2} \mathrm{O}$ oxidation. This suggests that the DSA $^{\circledR}$ coverage was not as good as expected from Fig. 3B, since the electrocatalytic properties of the $\mathrm{IrO}_{2}-\mathrm{Ta}_{2} \mathrm{O}_{5}$ layer were almost imperceptible. In contrast, the DSA ${ }^{\circledR}$ electrode synthesized by electrophoresis showed a greater overpotential for $\mathrm{O}_{2}$ evolution, being close to $0.7 \mathrm{~V}$ vs. Ag|AgCl. Therefore, it is expected that this kind of anode leads to a larger production of hydroxyl radicals from reaction (1), as will be investigated below.

In addition, the real area of each modified electrode was determined via the capacitance method described in Section 2. The values were 31.67, 16.67 and $11.67 \mathrm{~cm}^{2}$ for DSA $^{\circledR}$ electrodes prepared by EP, P and I, respectively, which results in a roughness factor of 42.22, 22.22 and 15.56, respectively. It is then evident that the electrophoretic deposition method leads to much larger electroactive areas, being twofold and threefold the value obtained by $\mathrm{P}$ and $\mathrm{I}$. Such a large area will be crucial for promoting the adsorption of organic pollutants, thus yielding a faster decontamination due to their enhanced reaction with adsorbed hydroxyl radicals.

\subsection{Determination of hydroxyl radicals}

First, the degradation of coumarin upon electro-oxidation at $30 \mathrm{~mA} \mathrm{~cm}{ }^{-2}$ with $\mathrm{DSA}^{\circledR}$ and Pt as the anode and cathode, respectively, was monitored by UV/vis spectroscopy aiming to compare the ability of DSA ${ }^{\circledR}$ prepared by EP and P to generate hydroxyl radicals. The values of the absorbance of coumarin at $277 \mathrm{~nm}$ during 120-min electrolyses are summarized in Table 1, whereas the spectra at time zero and at the end of each experiment are depicted in Fig. 5. The evolution of coumarin was quite similar using both DSA ${ }^{\circledR}$ electrodes, despite the smaller area of the DSA ${ }^{\circledR}$ prepared by painting, a mentioned above. This may be justified by the easy oxidation undergone by coumarin by some radical species 
like hydroxyl radical. In order to verify these results, the concentration of 7hydroxycoumarin resulting from the degradation of coumarin (see reaction (6)) was analyzed by HPLC with fluorescence detection. The values of 7-hydroxycoumarin concentration accumulated for $120 \mathrm{~min}$ are summarized in Table 2, whereas the concentration profiles with time are depicted in Fig. 6. As can be observed, the results confirm the production of hydroxyl radicals from reaction (1) using a DSA ${ }^{\circledR}$ modified by either EP or P, with a continuous increase in the concentration of the hydroxylated derivative. Although the amount of the latter compound was quite similar with both DSA ${ }^{\circledR}$ electrodes at the beginning of the electrolysis, at longer times the anode prepared by electrophoresis led to a larger concentration $(0.43 \mu \mathrm{M}$ vs. $0.40 \mu \mathrm{M})$, which suggests a better performance in terms of hydroxyl radical generation since the simultaneous anodic oxidation of 7-hydroxycoumarin is expected to be similar in both cases due to its much lower concentration compared to the parent compound.

In addition, the high stability of the $\mathrm{IrO}_{2}-\mathrm{Ta}_{2} \mathrm{O}_{5}$ coating obtained by EP was demonstrated from the extremely low amounts of Ir and Ta in solution $\left(<0.10 \mathrm{mg} \mathrm{L}^{-1}\right)$ after exhaustive electrolyses performed under acidic conditions $\left(0.5 \mathrm{M} \mathrm{H}_{2} \mathrm{SO}_{4}\right)$ at $30 \mathrm{~mA} \mathrm{~cm}{ }^{-2}$ for $24 \mathrm{~h}$.

After carrying out the trials at constant current, the generation of 7-hydroxycoumarin was also monitored at different constant anode potentials in the range 0-2.2 V vs. Ag|AgCl by testing values before and after the expected oxygen evolution. The DSA ${ }^{\circledR}$ electrode prepared by electrophoretic deposition, which yielded the highest concentration of 7hydroxycoumarin working at constant current, was used with the aim of finding the most convenient anode potential for performing subsequent test with DMPO. As shown in Fig. 7, the concentration of 7-hydroxycoumarin gradually increases as the applied potential is 
raised, reaching the maximum accumulation of the derivative at around 2.0-2.2 V vs. $\mathrm{Ag} \mid \mathrm{AgCl}$, whereupon a concentration plateau can be observed. This can be explained by the fact that the additional hydroxyl radicals generated from these potential values are selfdestroyed to yield $\mathrm{O}_{2}$.

Since the production of hydroxyl radicals is optimal within that potential range, the electro-oxidation of $10 \mathrm{mM}$ DMPO was performed at $2.2 \mathrm{~V}$ for $180 \mathrm{~min}$, and the corresponding UV/vis spectra obtained at the end of the electrolyses using a DSA ${ }^{\circledR}$ prepared by either EP or P are depicted in Fig. 8. The initial absorption spectrum of DMPO, which presents a clear peak at about $230 \mathrm{~nm}$, is also shown. At $180 \mathrm{~min}$, the absorption peak completely disappeared when the DSA ${ }^{\circledR}$ synthesized by electrophoresis was used, which confirms the action of very reactive oxygen species in the degradation. Note that the DSA $^{\circledR}$ obtained by painting was able to remove the DMPO signal as well, thus suggesting that hydroxyl radicals can be formed even if the coating is not as homogenous as expected.

In order to corroborate that the disappearance of the DMPO peak could be mainly explained by the formation of hydroxyl radicals from reaction (1), EPR analyses were conducted during analogous electro-oxidation trials at $2.2 \mathrm{~V}$ with the $\mathrm{DSA}^{\circledR}$ electrode prepared by electrophoretic deposition. As can be seen in Fig. 9, a clear EPR signal corresponding to the DMPO-` OH adduct was obtained with this $\mathrm{IrO}_{2}-\mathrm{Ta}_{2} \mathrm{O}_{5} \mid \mathrm{Ti}$ electrode, as revealed by the four peaks at expected G values, similarly to that reported in the literature $[33,34]$. Probably, these measurements are the most straightforward evidence of the ability of the manufactured DSA ${ }^{\circledR}$ electrodes to promote the formation of hydroxyl radicals.

\subsection{Degradation of hydrocarbons in water}


The performance of the best DSA ${ }^{\circledR}$ electrode among those prepared, i.e., the one synthesized by electrophoretic deposition, regarding the degradation of organic pollutants was tested by carrying out independent electro-oxidation treatments of $100 \mathrm{~mL}$ of solutions containing $0.5 \mu \mathrm{M}$ of a $\mathrm{PAH}$ in $0.05 \mathrm{M} \mathrm{Na}_{2} \mathrm{SO}_{4}$ as supporting electrolyte at $2.2 \mathrm{~V}$ vs. $\mathrm{Ag} \mid \mathrm{AgCl}$. Phenanthrene, naphthalene and fluoranthene, which have a high environmental relevance due to their presence and water and soil, were tested as model PAHs. For each hydrocarbon, the HPLC analyses to evaluate their concentration profiles were carried out until reaching the limit of quantification (LOD equal to $0.05,0.1$ and $0.15 \mu \mathrm{M}$ for phenanthrene, naphthalene and fluoranthene, respectively). As can be observed in Fig. 10, the selected DSA ${ }^{\circledR}$ allowed achieving the LOD after 180, 60 and 150 min, respectively. This means that the degradation percentages were always $>60 \%$, reaching $67 \%, 79 \%$ and 85\% for fluoranthene, naphthalene and phenanthrene at the indicated times. Electrooxidation with this DSA ${ }^{\circledR}$ was then a suitable method to remove PAHs from water within short times.

Finally, it was necessary to assess the ability of this method and electrode to cause the mineralization of the PAHs, not only their partial transformation into persistent intermediates. This was verified by means of TOC analyses for the three hydrocarbons and, as an example, Fig. 11 shows the time course of TOC during the treatment of $25 \mathrm{mg} \mathrm{L}^{-1}$ TOC of phenanthrene. A faster TOC abatement was achieved during the first minutes of electrolysis up to $120 \mathrm{~min}$, but it became slower over time due to the formation of more refractory intermediates, probably aliphatic carboxylic acids like oxalic or acetic [7]. However, after $420 \mathrm{~min}$, a $67 \%$ mineralization was reached, only remaining $8.5 \mathrm{mg} \mathrm{L}^{-1}$ TOC in solution. Similarly, Pulgarin et al. achieved the complete removal of 1,4benzoquinone, whereas the resulting aliphatic intermediates were only poorly degraded [6]. 


\section{Conclusions}

Surface analyses and electrochemical characterization have demonstrated that the preparation of DSA ${ }^{\circledR}$ electrodes by immersion is not convenient because inhomogeneous coatings with small active area are obtained. Conversely, painting and electrophoretic deposition allowed the formation of high quality coatings that behaved similarly regarding the degradation of coumarin, with formation of 7-hydroxycoumarin, although the active area of DSA ${ }^{\circledR}$ prepared by EP was significantly higher. Synthesis by EP suggested the formation of a slightly greater amount of hydroxyl radicals, whose presence was corroborated by EPR analyses. The performance of such a DSA ${ }^{\circledR}$ electrode for electrooxidation of aquesous solutions of PAHs is very promising, since it allowed reaching > $60 \%$ degradation within short times and $>67 \%$ mineralization after several hours. In

conclusion, DSA ${ }^{\circledR}$ electrodes synthesized by electrophoretic deposition have been proven a good material to generate very reactive oxygen species that are able to degrade hydrocarbons in water and, potentially, could find a future niche market in soil remediation because of the frequent problems related to hydrocarbon spills.

\section{Acknowledgements}

The authors wish to acknowledge the Consejo Nacional de Ciencia y Tecnología de los Estados Unidos Mexicanos (CONACyT) for its financial support to develop this project. The collaboration of Arelí Lerma and Ignacio Alvarez with laboratory activities is also acknowledged. R.A. Herrada is grateful to CONACyT by her scholarship to get her MSc degree in electrochemistry. I. Sirés thanks MINECO (Spain) for financial support under project CTQ2013-48897-C2-1-R, co-financed with FEDER funds. 


\section{References}

[1] K. Rajeshwar K, J.G. Ibanez, Environmental electrochemistry: fundamentals and applications in pollution abatement, Academic Press, USA, 1997.

[2] T. Volke, J.A. Velasco, Tecnologías de remediación para suelos contaminados, Instituto Nacional de Ecología (INE-SEMARNAT), Mexico, 2002.

[3] T. Volke, J.A. Velasco, D.A. de la Rosa, Suelos contaminados por metales y metaloides: muestreo y alternativas para su remediación, Instituto Nacional de Ecología (INE-SEMARNAT), Mexico, 2005.

[4] K.R. Reddy, C. Cameselle, Electrochemical remediation technologies for polluted soils, sediments and groundwater, Wiley, USA, 2009.

[5] E. Lichtfouse, J. Schwarzbauer, D. Robert (Eds.), Environmental chemistry for a sustainable world - Volume 2: Remediation of air and water pollution, Springer, The Netherlands, 2012.

[6] M. Panizza, G. Cerisola, Direct and mediated anodic oxidation of organic pollutants, Chem. Rev. 109 (2009) 6541-6569.

[7] I. Sirés, E. Brillas, M.A. Oturan, M.A. Rodrigo, M. Panizza, Electrochemical advanced oxidation processes: today and tomorrow: A review, Environ. Sci. Pollut. Res. 21 (2014) 8336-8367.

[8] A.M.Z. Ramalho, C.A. Martínez-Huitle, D.R. da Silva, Application of electrochemical technology for removing petroleum hydrocarbons from produced water using a DSAtype anode at different flow rates, Fuel 89 (2010) 531-534. 
[9] J. Muff, E.G. Søgaard, Electrochemical degradation of PAH compounds in process water: a kinetic study on model solutions and a proof of concept study on runoff water from harbour sediment purification, Water Sci. Technol. 61 (2010) 2043-2051.

[10]A. Yaqub, M.H. Isa, H. Ajab, Electrochemical degradation of polycyclic aromatic hydrocarbons in synthetic solution and produced water using a $\mathrm{Ti} / \mathrm{SnO}_{2}-\mathrm{Sb}_{2} \mathrm{O}_{5}-\mathrm{RuO}_{2}$ anode. J. Environ. Eng. 141 (1) (2015) 1-8.

[11] O. Scialdone, Electrochemical oxidation of organic pollutants in water at metal oxide electrodes: A simple theoretical model including direct and indirect oxidation processes at the anodic surface, Electrochim. Acta 54 (2009) 6140-6147.

[12] O. Scialdone, S. Randazzo, A. Galia, G. Filardo, Electrochemical oxidation of organics at metal oxide electrodes: The incineration of oxalic acid at $\mathrm{IrO}_{2}-\mathrm{Ta}_{2} \mathrm{O}_{5}\left(\mathrm{DSA}-\mathrm{O}_{2}\right)$ anode, Electrochim. Acta 54 (2009) 1210-1217.

[13]E. Pepprah, M.V. Khire, Electroremediation of naphthalene in aqueous solution using alternating and direct currents. J. Environ. Eng. 134 (1) (2008) 32-41.

[14]H.B. Beer, Electrode and coating therefore, US patent 3,632,498 (1972).

[15] M. Pérez-Corona, A. Corona, E.D. Beltrán, J. Cárdenas, E. Bustos, Evaluation of $\mathrm{IrO}_{2-}$ $\mathrm{Ta}_{2} \mathrm{O}_{5} \mid \mathrm{Ti}$ electrodes employed during the electroremediation of hydrocarboncontaminated soil, Sustain. Environ. Res. 23 (2013) 279-284.

[16] O. López, I. González, J.L. Nava, Electrochemical incineration of indigo textile dye in filter-press-type FM01-LC electrochemical cell using mesh-DSA anode, ECS Trans. 15 (2008) 395-402.

[17] R. Chaiyont, C. Badoe, C. Ponce de León, J.L. Nava, F.J. Recio, I. Sirés, P. Herrasti, F.C. Walsh, Decolorization of Methyl Orange dye at $\mathrm{IrO}_{2}-\mathrm{SnO}_{2}-\mathrm{Sb}_{2} \mathrm{O}_{5}$ coated titanium anodes, Chem. Eng. Technol. 36 (2013) 123-129. 
[18]C. Salazar, I. Sirés, R. Salazar, H.D. Mansilla, C.A. Zaror, Treatment of cellulose bleaching effluents and their filtration permeates by anodic oxidation with $\mathrm{H}_{2} \mathrm{O}_{2}$ production, J. Chem. Technol. Biotechnol. 90 (2015) 2017-2026.

[19]P. Duby, The history of progress in dimensionally stable anodes, JOM 45 (1993) 4143.

[20] H.B. Beer, The invention and industrial development of metal anodes, J. Electrochem. Soc. 127 (1980) 303C-307C.

[21]C. Comninellis, G.P. Vercesi, Characterization of DSA®-type oxygen evolving electrodes: Choice of a coating, J. Appl. Electrochem. 21 (1991) 335-345.

[22] J.-Y. Lee, An investigation on the electrochemical characteristics of $\mathrm{Ta}_{2} \mathrm{O}_{5}-\mathrm{IrO}_{2}$ anodes for the application of electrolysis process, Mater. Sci. Appl. 2 (2011) 237-243.

[23] S. Fierro, A. Kapałka, C. Comninellis, Electrochemical comparison between $\mathrm{IrO}_{2}$ prepared by thermal treatment of iridium metal and $\mathrm{IrO}_{2}$ prepared by thermal decomposition of $\mathrm{H}_{2} \mathrm{IrCl}_{6}$ solution, Electrochem. Commun. 12 (2010) 172-174.

[24] M.P. Groover, Fundamentos de manufactura moderna: materiales, procesos y sistemas. Prentice-Hall Hispanoamericana SA, Mexico, 1997.

[25]B.-S. Li, A. Lin, F.-X. Gan, Preparation and electrocatalytic properties of $\mathrm{Ti}^{-/ \mathrm{IO}_{2}-}$ $\mathrm{Ta}_{2} \mathrm{O}_{5}$ anodes for oxygen evolution, Trans. Nonferrous Metals Soc. China 16 (2006) 1193-1199.

[26]L.K. Xu, J.D. Scantlebury, Electrochemical surface characterization of $\mathrm{IrO}_{2}-\mathrm{Ta}_{2} \mathrm{O}_{2}$ coated titanium electrodes in $\mathrm{Na}_{2} \mathrm{SO}_{4}$ solution. J. Electrochem. Soc. 150 (2003) B288B293. 
[27] J. Krýsa, L. Kule, R. Mráz, I. Roušar, Effect of coating thickness and surface treatment of titanium on the properties of $\mathrm{IrO}_{2}-\mathrm{Ta}_{2} \mathrm{O}_{5}$ anodes, J. Appl. Electrochem. 26 (1996) 999-1005.

[28] Y.-Y. Chen, T. Zhang, X. Wang, Y.-Q. Shao, D. Tang, Phase structure and microstructure of a nanoscale $\mathrm{TiO}_{2}-\mathrm{RuO}_{2}-\mathrm{IrO}_{2}-\mathrm{Ta}_{2} \mathrm{O}_{5}$ anode coating on titanium, $\mathrm{J}$. Am. Ceram. Soc. 91 (2008) 4154-4157.

[29]M. Yousefpour, A. Shokuhy, Electrodeposition of $\mathrm{TiO}_{2}-\mathrm{RuO}_{2}-\mathrm{IrO}_{2}$ coating on titanium substrate, Superlattices Microstruct. 51 (2012) 842-853.

[30]S. Trasatti, O.A. Petrii, Real surface area measurements in electrochemistry, Pure Appl. Chem. 63(5) (1991) 711-734.

[31] C. Sicard-Roselli, E. Brun, M. Gilles, G. Baldacchino, C. Kelsey, H. McQuaid, C. Polin, N. Wardlow, F. Currell, A new mechanism for hydroxyl radical production in irradiated nanoparticle solutions, Small 10 (2014) 3338-3346.

[32] T. Maezono, M. Tokumura, M. Sekine, Y. Kawase, Hydroxyl radical concentration profile in photo-Fenton oxidation process: generation and consumption of hydroxyl radicals during the discoloration of azo-dye Orange II, Chemosphere 82 (2011) 14221430.

[33] C. Comninellis, G. Chen, Electrochemistry for the environment, Springer, New York, 2010.

[34]B. Marselli, J. Garcia-Gomez, P.-A. Michaud, M.A. Rodrigo, Ch. Comninellis, Electrogeneration of hydroxyl radicals on boron-doped diamond electrodes, $\mathrm{J}$. Electrochem. Soc. 150 (2003) D79-D83. 
[35]B. Borbón, M.T. Oropeza-Guzman, E. Brillas, I. Sirés, Sequential electrochemical treatment of dairy wastewater using aluminum and DSA-type anodes, Environ. Sci. Pollut. Res. 21 (2014) 8573-8584. 


\section{Table and Figure captions}

Table 1. Comparative time course of absorbance values at $277 \mathrm{~nm}$ obtained during the treatment of coumarin using either the $\mathrm{DSA}^{\circledR}$ modified by electrophoretic deposition or the one prepared by painting. In both kinds of electrolysis, trials were made in triplicate.

Table 2. 7-Hydroxycoumarin concentration measured by HPLC coupled to a fluorescence detector at different reaction times upon electro-oxidation of coumarin using either the DSA $^{\circledR}$ modified by electrophoretic deposition or the one prepared by painting. Trials were always made in triplicate.

Fig. 1. Scanning electron micrographies of the surfaces of the three $\mathrm{DSA}^{\circledR}$ electrodes at (A) 2000x and (B) 5000x, where: EP = electrophoretic; P = Painting; I = Immersion.

Fig. 2. EDX microanalysis of $\mathrm{DSA}^{\circledR}$ electrodes prepared by (A) electrophoretic deposition, (B) painting and (C) immersion.

Fig. 3. Mapping obtained from EDX analysis at 100x with $15 \mathrm{keV}$ for $\mathrm{DSA}^{\circledR}$ electrodes prepared by (A) electrophoretic deposition and (B) painting.

Fig. 4. Cyclic voltammograms of $0.75 \mathrm{~cm}^{2} \mathrm{DSA}^{\circledR}$ electrodes synthesized by electrophoretic deposition and painting compared to that of a raw titanium substrate.

Fig. 5. UV/vis spectra of coumarin after $120 \mathrm{~min}$ of electrolysis of solutions with $0.3 \mathrm{mM}$ in $0.5 \mathrm{M} \mathrm{H}_{2} \mathrm{SO}_{4}$ as supporting electrolyte, at $30 \mathrm{~mA} \mathrm{~cm}{ }^{-2}$ and room temperature under constant stirring. The best $\mathrm{DSA}^{\circledR}$ electrodes $\left(0.75 \mathrm{~cm}^{2}\right)$ prepared by electrophoretic deposition and painting were used as the anode. The spectrum of coumarin at time zero is also shown. 
Fig. 6. Time course of 7-hydroxycoumarin concentration accumulated during the experiments described in Fig. 5.

Fig. 7. Time course of 7-hydroxycoumarin concentration accumulated during the electrooxidation of $0.3 \mathrm{mM}$ coumarin in $0.5 \mathrm{M} \mathrm{H}_{2} \mathrm{SO}_{4}$ at constant anode potential in the range 0$2.2 \mathrm{~V}$ vs. Ag|AgCl using a $0.75 \mathrm{~cm}^{2} \mathrm{DSA}^{\circledR}$ electrode prepared by electrophoretic deposition.

Fig. 8. UV/vis spectra of DMPO after $180 \mathrm{~min}$ of electrolysis of solutions with $10 \mathrm{mM}$ in $0.5 \mathrm{M} \mathrm{H}_{2} \mathrm{SO}_{4}$ as supporting electrolyte, at $2.2 \mathrm{~V}$ vs. Ag|AgCl using a $0.75 \mathrm{~cm}^{2} \mathrm{DSA}^{\circledR}$ electrode prepared by either electrophoretic deposition or painting. The spectrum of DMPO at time zero is also shown.

Fig. 9. EPR spectrum showing the signal of the DMPO- ${ }^{\circ} \mathrm{OH}$ adduct generated during the electrolysis of DMPO performed as described in Fig. 8 using the DSA ${ }^{\circledR}$ electrode prepared by electrophoretic deposition.

Fig. 10. Time course of phenantrene, naphthalene and fluoranthene concentration during independent electro-oxidation treatments of $100 \mathrm{~mL}$ of solutions containing $0.5 \mu \mathrm{M}$ of the hydrocarbon in $0.05 \mathrm{M} \mathrm{Na}_{2} \mathrm{SO}_{4}$ as supporting electrolyte at $2.2 \mathrm{~V}$ vs. Ag|AgCl using a 0.75 $\mathrm{cm}^{2}$ DSA $^{\circledR}$ electrode prepared by electrophoretic deposition, at room temperature under constant stirring.

Fig. 11. TOC values vs. time for the electro-oxidation of $0.5 \mu \mathrm{M}$ phenanthrene under the conditions described in Fig. 10. 